\title{
STRATEGI PENGEMBANGAN PENGELOLAAN RANTAI PASOK DALAM PENGOLAHAN SAMPAH PLASTIK
}

\author{
Kikis Dinar Yuliesti ${ }^{1}$, Suripin ${ }^{1}$, dan Sudarno ${ }^{1}$ \\ 1Universitas Diponegoro, Kota Semarang; e-mail: kikisdinarciptakarya@gmail.com
}

\begin{abstract}
ABSTRAK
Pengelolaan sampah rumah tangga masih menjadi salah satu masalah serius yang terjadi di kota besar. Pertambahan jumlah penduduk setiap tahunnya akan mempengaruhi volume, jenis dan karakteristik sampah yang dihasilkan setiap harinya. Dari hasil penelitian lapangan yang dilakukan di Kecamatan Semarang Tengah pada Tahun 2017 menunjukkan bahwa sampah yang dihasilkan mencapai hampir 0,98 kg per orang setiap harinya. Adapun sampah yang dihasilkan terdiri dari 77,5\% sampah organik, 13,5 \% sampah plastik, 5,5 \% sampah kardus dan kertas, 2,2 \% logam / kaleng dan sisanya adalah kaca dan lainnya. Dari komposisi tersebut, sampah plastik merupakan sampah non organik yang memiliki prosentase tertinggi. Subjek dalam penelitian ini adalah pelaku dalam rantai pasok pengelolaan sampah plastik. Dari subjek penelitian juga didapatkan faktor internal dan eksternal yang akan digunakan untuk menganalisis kekuatan (strengths), kelemahan (weaknesses), peluang (opportunities), dan ancaman (threats) dalam meningkatkan dan menjaga keberlanjutan pengelolaan sampah plastik di Kecamatan Semarang Tengah. Suatu sistem penyediaan bahan baku, proses produksi hingga proses pemasaran sampai ke tangan konsumen, dibutuhkan dukungan teknologi baik berupa aplikasi sederhana yang memberikan informasi tentang ketersediaan jenis dan jumlah bahan baku yang terupdate, sehingga dapat mempersingkat waktu produksi. Selain itu juga perlu dukungan sistem informasi untuk membantu pemasaran produk daur ulang, sehingga jangkauan pengguna / konsumen akan lebih banyak dan lebih luas. Keberadaan teknologi informasi memegang peranan penting sebagai media untuk mempercepat terpenuhinya supply dan demand serta menjamin keberlangsungan dan keberlanjutan usaha.
\end{abstract}

Kata kunci: Sampah plastik, Daur ulang, Rantai pasok

\begin{abstract}
Household waste management is still one of the serious problems that occur in big cities. The increase of population each year will affect the volume, type and characteristics of waste produced every day. From the results of field research conducted in the District of Central Semarang in 2017 showed that the waste generated reached almost $0.98 \mathrm{~kg}$ per person every day. The waste generated consists of $77.5 \%$ organic waste, $13.5 \%$ plastic waste, $5.5 \%$ cardboard and paper waste, $2.2 \%$ metal / can and the rest is glass and others. From the results showed that plastic waste is non-organic waste which has the highest percentage. The subjects in this study were actors in the supply chain of plastic waste management. The research subjects also obtained internal and external factors that will be used to analyze strengths, weaknesses, opportunities and threats in improving and maintaining the sustainability of plastic waste management in Central Semarang District. A system of supplying raw materials, the production process to the marketing process up to the hands of consumers, technology support is needed in the form of a simple application that provides information about the availability of types and quantities of updated raw materials, so as to shorten the production time. It also needs the support of information systems to help marketing recycled products, so that the coverage area of users / consumers will be more and wider. The existence of information technology plays an important role as a medium to accelerate the fulfillment of supply and demand and to ensure the sustainability of the business.
\end{abstract}

Keywords: Plastic waste, Recycling, Supply chain

Citation: Yuliesti, K.D., Suripin, dan Sudarno. (2020). Strategi Pengembangan Pengelolaan Rantai Pasok dalam Pengolahan Sampah Plastik. Jurnal Ilmu Lingkungan, 18(1), 126-132, doi:10.14710/jil.18.1.126-132

\section{Pendahuluan}

Pengelolaan sampah rumah tangga masih menjadi salah satu masalah serius yang terjadi di kota besar, Kota Semarang sebagai Ibukota Provinsi Jawa Tengah menjadi salah satu kota yang merupakan representasi kota besar di Pulau Jawa. Pertambahan jumlah penduduk setiap tahunnya akan mempengaruhi volume, jenis dan karakteristik sampah yang dihasilkan setiap harinya. Dari hasil penelitian lapangan yang dilakukan di Kecamatan Semarang Tengah pada Tahun 2017 menunjukkan bahwa sampah yang dihasilkan mencapai hampir 0,98 $\mathrm{kg}$ per orang setiap harinya. Adapun sampah yang dihasilkan terdiri dari 77,5\% sampah organik, 13,5\% sampah plastik, 5,5\% sampah kardus dan kertas, 2,2\% logam / kaleng dan sisanya adalah kaca dan lainnya. Dari komposisi tersebut, sampah plastik merupakan 
sampah non organik yang memiliki prosentase tertinggi.

Sampah plastik adalah jenis sampah yang paling sulit diuraikan oleh tanah. Jika kita membuang sampah plastik hari ini, hingga 80 tahun mendatang pun sampah plastik ini pun belum bisa teruraikan. Sampah plastik yang ada berasal dari kemasan pembungkus makanan maupun kemasan pembungkus produk kebutuhan rumah tangga. Tidak dapat dipungkiri apabila produk yang berasal dari plastik memiliki manfaat dalam kehidupan seharihari, namun juga memiliki dampak buruk bagi lingkungan.

Pengelolaan sampah plastik yang dilakukan belum bisa secara signifikan mengurangi volume sampah plastik yang dibuang ke TPA. Selain itu dalam upaya keberlanjutan pengelolaan sampah plastik juga terkendala dengan faktor - faktor yang yang dihadapi oleh pelaku rantai pasok pengelolaan sampah plastik. Pengelolaan sampah menurut Peraturan Pemerintah Republik Indonesia Nomor 81 Tahun 2012 tentang Pengelolaan Sampah Rumah Tangga dan Sampah Sejenis Sampah Rumah Tangga adalah suatu aktivitas sistematis, menyeluruh, dan berkesinambungan dalam pengurangan dan penanganan sampah. Sedangkan menurut Peraturan Daerah Kota Semarang Nomor 6 Tahun 2012 tentang Pengelolaan Sampah, TPST adalah tempat dilaksanakannya aktivitas pengumpulan, pemilihan, penggunaan ulang, pendauran ulang, pengolahan, dan pemrosesan akhir dari sampah.

Dalam proses pengelolaan sampah berkelanjutan tidak bisa lepas dari aktivitas Rantai Pasok (Supply Chain) yang didefinisikan sebagai serangkaian aktivitas dalam proses transformasi dan distribusi bahan baku sampai menjadi produk jadi kepada para pelanggan / konsumen akhir (Anwar Sariyun Naja, 2011). Manajemen rantai pasokan (supply chain management) adalah pengintegrasian aktivitas pengadaan bahan dan pelayanan, pengubahan menjadi barang setengah jadi dan produk akhir, serta pengiriman ke pelanggan. Seluruh aktivitas ini mencakup aktivitas pembeliaan dan outsourcing, ditambah fungsi lain yang penting bagi hubungan antara pemasok dengan distributor. Rantai pasok adalah suatu sistem yang terdiri dari beberapa pihak/pelaku untuk mengubah bahan dasar menajdi produk jadi dan memasoknya sesuai nilai yang diminta (Natsir, 2011 dalam Setiawan, 2011). Menurut Trisna (2012) dalam Sampit et al. (2016), model rantai pasokan (supply chain) yaitu gambaran mengenai hubungan mata rantai antara pelaku yang terhubung satu dengan yang lain. Rantai ini merupakan jaringan dari berbagai organisasi yang saling berhubungan untuk membangun sebuah rantai pemasok dan memaksimalkan nilai bagi pelanggan. Sistem rantai pasok suatu produk secara simultan mencakup sistem rantai nilai yang menyertai kualitas produk dalam sistem jaringan yang kompleks untuk berbagai pemangku kepentingan dari hulu maupun hilir (Setiawan, 2011). Pada Supply Chain terdapat 3 macam aliran yang dikelola. Pertama, aliran barang dari hulu (upstream) ke hilir (downstream). Kedua, aliran uang dan sejenisnya dari hilir ke hulu. Ketiga, aliran informasi yang terjadi dari hilir atau sebaliknya. Kombinasi dari ketiga aliran tersebut yaitu untuk menciptakan dan menghantarkan suatu produk ke tangan konsumen akhir. Pengoptimalan rantai pasok tidak lepas dari menciptakan alur informasi secara mudah dan akurat dalam mata rantai tersebut. Peran teknologi informasi menjadi salah satu cara untuk mempercepat dan mempertemukan penawaran (supply) dan permintaan (demand).

Supply Chain Management (SCM) adalah rangkaian kegiatan yang diperlukan untuk merencanakan, mengendalikan, dan menjalankan arus produk. Ini meliputi proses perolehan bahan baku, proses produksi, hingga distribusi produk ke konsumen akhir, dengan cara yang paling efisien dan hemat biaya. SCM merupakan usaha yang luas dan kompleks yang bergantung pada setiap mitra - dari pemasok hingga produsen dan seterusnya - supaya dapat berjalan dengan baik. Tujuan dari manajemen rantai pasokan sendiri adalah untuk memaksimalkan nilai pelanggan dan mendapatkan keunggulan kompetitif di pasar.

\section{Metode}

Penelitian ini merupakan pengembangan penelitian strategi pengembangan pengelolaan sampah domestik dengan studi kasus di kecamatan Semarang Tengah Kota Semarang. Pemilihan sampel dalam penelitian ini memakai metode propotionate stratified random sampling, maksudnya pengambilan sampel dari anggota populasi dilakukan secara acak dengan memperhatikan strata yang ada, anggota populasi dianggap tidak homogen. (Ismiyati, 2011). Maksudnya tidak homogen, sample merupakan individu yang tinggal di permukiman yang teratur/tertata dengan baik dan individu yang tinggal di permukiman yang kurang tertata dengan baik, kepadatan penduduk tinggi, dan cenderung kumuh. Populasi yang dimaksud adalah wilayah obyek/subjek yang mempunyai kuantitas dan karakteristik tertentu yang ditetapkan oleh peneliti untuk dipelajari dan kemudian ditarik kesimpulannya. Populasinya adalah rumah tangga yang ada di Kecamatan Semarang Tengah. Dari total 105 responden, terdapat 10 responden yang memiliki mata pencaharian sebagai pedagang makanan dan minuman kaki lima yang meghasilkan sampah plastik dengan jenis yang sama dan jumlah cukup besar setiap harinya. Subjek dalam penelitian ini adalah pelaku dalam rantai pasok pengelolaan sampah plastik. Adapun pelaku tersebut antara lain rumah tangga yang memiliki usaha sebagai pedagang kaki lima penghasil timbulan sampah plastik, pengelola bank sampah, pengolah sampah plastik dan pengguna hasil olahan sampah plastik. Dari pelaku yang berperan dalam rantai pasok pengelolaan sampah tersebut akan dapat diidentifikasi rantai pasok pengelolaan sampah eksisting, kemudian dapat 
dianalisa rantai nilainya serta rantai nilai yang memiliki nilai tambah terbesar dalam pengelolaan sampah plastik mulai dari sumber hingga menjadi barang dengan nilai ekonomis. Dari subjek penelitian juga didapatkan faktor internal dan eksternal yang akan digunakan untuk menganalisis kekuatan (strengths), kelemahan (weaknesses), peluang (opportunities), dan ancaman (threats) dalam meningkatkan dan menjaga keberlanjutan pengelolaan sampah plastik di Kecamatan Semarang Tengah.

\section{Hasil dan Pembahasan}

Rumah tangga sebagai penghasil sampah merupakan pelaku supply atau pemberi penawaran bahan baku sampah plastik. Aktivitas utamanya yaitu menghasilkan sampah plastik dari aktivitas seharihari, dalam hal ini sebagai pedagang kaki lima yang menjual makanan dan minuman kemasan. Sampah yang dihasilkan setiap hari cukup banyak jenis dan jumlahnya. Jenis sampah tersebut dalam periode 8 (delapan) hari sebagaimana Metode Pengambilan dan Pengukuran Contoh Timbulan Sampah Perkotaan, Badan Standarisasi Nasional, SNI 19.3964.1994. Sampah kemasan tersebut biasanya dikumpulkan dalam satu wadah sampah bercampur dengan sampah lain termasuk sampah organik, selanjutnya sampah akan diambil oleh petugas pengangkut sampah untuk dibawa ke tempat pembuangan sampah sementara (TPS). Dari 10 (sepuluh) responden yang dijadikan sample dalam penelitian, maka diperoleh jenis dan jumlah sampah sebagaimana pada Tabel. 1.

Tabel 1. Jenis dan jumlah sampah plastik kemasan makanan dan minuman

\begin{tabular}{|c|c|c|c|c|c|c|c|c|c|c|c|}
\hline \multirow{2}{*}{ No } & \multirow{2}{*}{ Jenis Sampah Kemasan } & \multicolumn{8}{|c|}{ Banyaknya Sampah Kemasan Makanan Selama 8 Hari } & \multirow{2}{*}{ Jml } & \multirow{2}{*}{$\begin{array}{c}\text { Rata-Rata/ } \\
\text { Hari }\end{array}$} \\
\hline & & 1 & 2 & 3 & 4 & 5 & 6 & 7 & 8 & & \\
\hline 1 & Kemasan Minuman Instan A & 38 & 35 & 38 & 20 & 25 & 24 & 29 & 30 & 239 & 30 \\
\hline 2 & Kemasan Minuman Instan B & 21 & 14 & 30 & 22 & 39 & 36 & 24 & 27 & 213 & 27 \\
\hline 3 & Kemasan Minuman Instan C & 34 & 28 & 33 & 29 & 27 & 19 & 32 & 33 & 235 & 29 \\
\hline 4 & Kemasan Minuman Instan D & 39 & 24 & 37 & 26 & 32 & 29 & 37 & 38 & 262 & 33 \\
\hline 5 & Kemasan Minuman Instan E & 45 & 21 & 33 & 28 & 34 & 24 & 34 & 34 & 253 & 32 \\
\hline 6 & Kemasan Minuman Instan F & 29 & 24 & 36 & 32 & 29 & 24 & 32 & 22 & 228 & 29 \\
\hline 7 & Kemasan Minuman Instan G & 46 & 29 & 43 & 37 & 25 & 39 & 64 & 49 & 332 & 42 \\
\hline 8 & Kemasan Mi Instan A & 19 & 16 & 26 & 29 & 30 & 44 & 22 & 34 & 220 & 28 \\
\hline 9 & Kemasan Mi Instan B & 35 & 24 & 39 & 33 & 24 & 58 & 35 & 23 & 271 & 34 \\
\hline 10 & Kemasan Mi Instan C & 30 & 24 & 33 & 36 & 27 & 59 & 29 & 23 & 261 & 33 \\
\hline 11 & Kemasan Mi Instan D & 32 & 18 & 49 & 27 & 39 & 60 & 31 & 49 & 305 & 38 \\
\hline
\end{tabular}

Dari Tabel. 1 dapat diketahui bahwa dalam periode 8 (delapan) hari terdapat 11 jenis sampah yang sama dari 10 (sepuluh) responden, dengan ratarata jumlah sampah plastik kemasan yang dihasilkan setiap harinya paling sedikit 27 kemasan dan paling banyak 42 kemasan. Sampah tersebut semuanya langsung diangkut ke TPS tanpa ada proses pemilahan ataupun pengolahan, selanjutnya dari TPS dibawa ke TPA. Begitulah aktivitas harian dari pelaku penghasil sampah, mereka menganggap bahwa sampah plastik kemasan tersebut memang sudah tidak memiliki nilai manfaat lagi, sehingga harus segera dibuang ke tempat pembuangan sampah. Pelaku penghasil sampah ini merasa telah melakukan hal yang sudah sebagaimana mestinya dilakukan, dengan membayar iuran untuk pengangkutan sampah dari sumber menuju TPS, namun mereka tidak memikirkan bagaimana akibatnya apabila hal ini dilakukan secara terus - menerus. Volume sampah mulai dari sumber sampai dengan TPA sama, belum ada upaya untuk mengurangi volume sampah, sebagaimana digambarkan pada Gambar. 1 Alur sampah dari sumber menuju TPA di bawah ini.

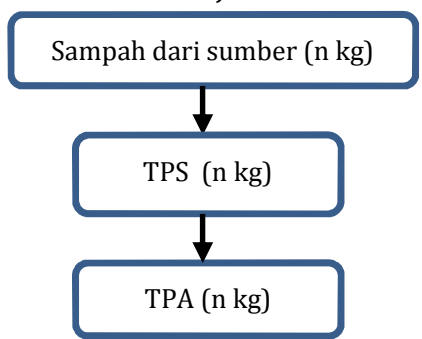

Gambar. 1 Alur sampah dari sumber menuju TPA

Dalam upaya pengurangan jumlah sampah plastik yang akan diangkut ke TPA, pemilahan sampah dari sumber merupakan kegiatan utama yang harus dilakukan, sehingga alur sampah plastik tersebut akan berubah menjadi sebagaimana Gambar 2.

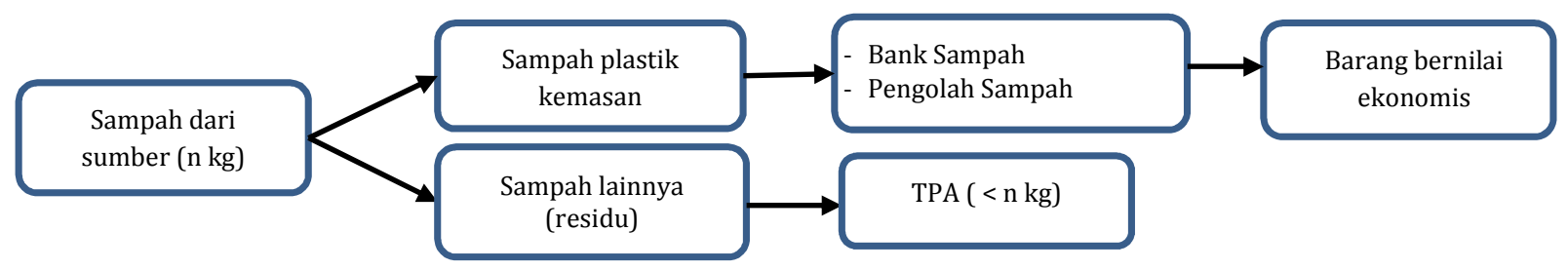

Gambar. 2 Alur sampah plastik dari sumber menuju TPA

Dari alur Gambar. 2 di atas, dapat diketahui bahwa volume sampah yang dihasilkan pada sumber menuju ke TPA akan berkurang. Sedangkan sampah kemasan yang sudah dipilah menjadi bahan baku 
untuk diolah menjadi barang yang memiliki nilai manfaat dan nilai ekonomi bagi pelaku pengolah sampah.

Bank sampah yang terdapat di Kecamatan Semarang Tengah dikelola oleh masyarakat. Namun kegiatan ini belum berjalan dengan optimal. Kegiatan bank sampah yang ada di Kecamatan Semarang Tengah dikelola oleh Ibu - ibu Pemberdayaan Kesejahteraan Keluarga (PKK), namun kegiatan ini hanya berjalan dengan periode waktu tertentu, ada yang satu minggu sekali, dua minggu sekali dan satu bulan sekali. Bahkan ada beberapa bank sampah yang aktivitasnya tidak berlanjut. Kegiatan pilah sampah pada sumber belum secara konsisten diterapkan menjadi faktor penyebab ketidakberlanjutan kinerja bank sampah. Pada Gambar. 3 di bawah ini menampilkan alur kerja bank sampah.

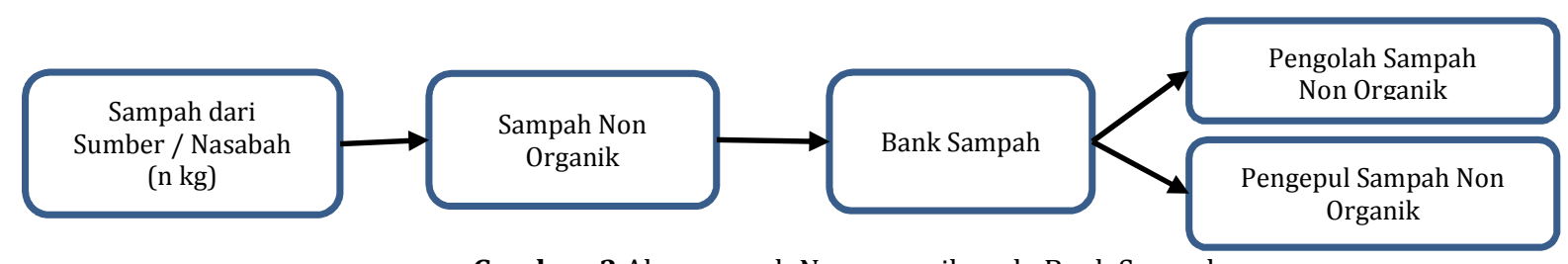

Gambar. 3 Alur sampah Non-organik pada Bank Sampah

Kegiatan pengolahan sampah plastik menjadi barang yang bernilai ekonomis dilakukan oleh kelompok masyarakat yang ada di Kecamatan Semarang Tengah. Aktifitas kelompok masyarakat ini masih bersifat kegiatan sambilan, artinya tidak dilakukan setiap hari dan waktu yang lama. Keterbatasan jenis dan jumlah bahan baku juga menjadi faktor penghambat bagi keberlangsungan kegiatan pengolahan sampah. Kesulitan untuk mendapatkan jenis sampah plastik yang sama dengan jumlah yang banyak menjadi kendala dalam pengolahan sampah. Sebagai gambaran untuk menghasilkan satu jenis produk daur ulang misalnya saja tas dengan ukuran $30 \mathrm{~cm} \times 45 \mathrm{~cm}$ dibutuhkan sekitar 415 buah plastik kemasan dengan jenis yang sama. Sehingga untuk mendapatkan bahan baku yang sesuai dengan kebutuhan untuk menghasilkan satu produk daur ulang membutuhkan waktu lebih dari satu minggu. Kegiatan mengolah sampah menjadi barang yang bernilai ekonomis membutuhkan ide dan kreatifitas yang tinggi, sehingga barang yang dihasilkan memiliki nilai estetis dan nilai manfaat yang tinggi sehingga layak untuk dijual. Kegiatan mengolah sampah menjadi barang yang bernilai ekonomis juga membutuhkan komponen pelengkap lainnya sebagai pendukung yang dapat meningkatkan nilai jual produk. Misalnya saja untuk membuat tas dari sampah plastik, tentunya dibutuhkan komponen pelengkap seperti resleting tas, tali untuk tas, dan acessories tambahan lainnya. Komponen pelengkap tersebut akan berdampak pada hasil produk daur ulang yang dihasilkan, serta mempengaruhi harga jual produk.

Berikut merupakan ilustrasi perhitungan biaya produksi dan nilai jual sampah yang telah didaur ulang.

1 kemasan dibeli oleh $=$ Rp. 100 pengrajin

\footnotetext{
1 produk tas ukuran kecil (waktu selama 2 hari) harga jual Rp. 80.000

200 Kemasan $x$ Rp. $100=20.000$ $\begin{array}{llll}\text { Upah tenaga/hari } & =10.000 & \times 2 \mathrm{hr}=20.000 \\ \text { Material pelengkap/ } & =20.000\end{array}$ asesories
}

$\begin{array}{lcl}\text { Lain-lain } & = & 5.000 \\ \text { Total Biaya produksi } & \text { Rp. } & 65.000 \\ & = & 80.000-65.000 \\ & =15.000 \\ & \mathbf{2 5 \%}\end{array}$

1 produk tas ukuran besar (waktu selama 3 hari) harga jual Rp. 150.000

$\begin{array}{lll}500 \quad \text { Kemasan x Rp. } 100 & =50.000 \\ \text { Upah tenaga/hari } & =10.000 \quad \mathrm{X} 3 \mathrm{hr}=30.000 \\ \text { Material pelengkap/ } & =30.000 \\ \begin{array}{l}\text { asesories } \\ \text { Lain-lain }\end{array} & =5.000 \\ \text { Total Biaya produksi } & \mathrm{Rp} & 115.000 \\ \text { Keuntungan } & =150.000-115.000 \\ & =35.000 \\ & & \mathbf{3 2 \%}\end{array}$

Dari ilustrasi di atas menunjukkan bahwa usaha kecil dalam upaya mendaur-ulang sampah plastik memiliki potensi keuntungan yang cukup baik, yaitu berkisar antara $25-30 \%$ dari total biaya produksi. Tentunya hal tersebut harus diikuti dengan upaya edukasi dan motivasi kepada masyarakat untuk menggunakan barang hasil daur ulang. Sehingga dapat memberikan jaminan keberlangsungan usaha kecil dalam mendaur ulang sampah, serta mengurangi timbulan sampah yang dibuang ke TPA.

Proses pemasaran produk daur ulang dilakukan langsung kepada konsumen, maupun melalui keikutsertaan dalam kegiatan pameran yang biasanya diselenggarakan oleh pemerintah atau stakeholder pemerhati usaha daur ulang sampah. Produk hasil daur ulang ini sebagian besar dibuat sesuai pesanan, pengolah sampah tidak menyediakan stok produk daur ulang dengan jumlah banyak. Sehingga bagi konsumen yang membutuhkan produk daur ulang harus melakukan pemesanan terlebih dahulu (made by order) . Lama waktu penyelesaian tergantung dengan ketersediaan bahan baku, dan tingkat kesulitan desain produk. Sedangkan harga produk hasil daur ulang tersebut tergantung dengan jumlah bahan baku yang digunakan, jenis bahan baku yang digunakan, komponen pelengkap dan tingkat kesulitan desain produk. Hubungan antara pengolah 
sampah dengan konsumen atau pengguna adalah sebagai supply. Sedangkan hubungan antara pengolah sampah dengan penyedia bahan baku sampah plastik
(Bank Sampah dan pedagang kaki lima) merupakan demand. Alur kegiatan pengolah sampah dapat digambarkan sebagaimana Gambar. 4.

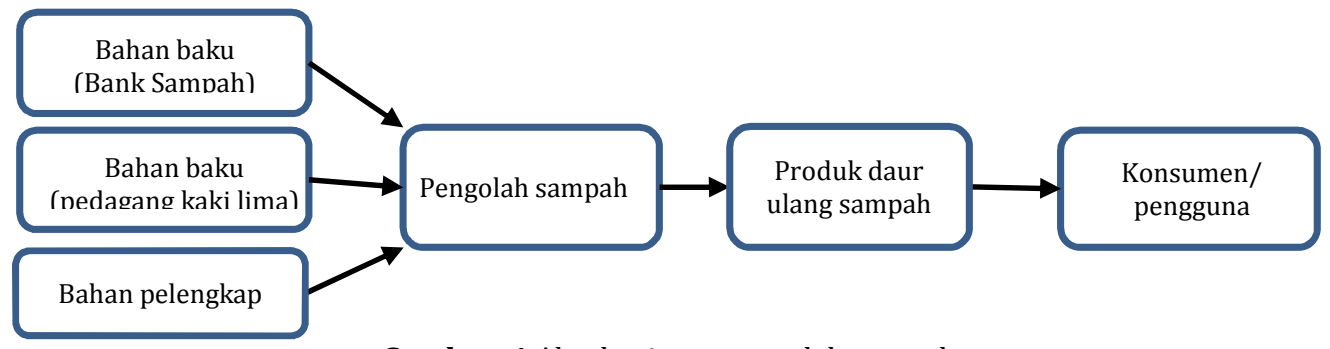

Gambar. 4 Alur kegiatan pengolah sampah

Konsumen atau pengguna produk hasil daur ulang merupakan aktor yang memiliki peran penting dalam upaya pengurangan sampah plastik. Pengguna produk daur ulang berasal dari unsur perorangan, komunitas, ataupun perusahaan. Unsur perorangan bisa dimulai dari diri kita sendiri, artinya dengan kita sendiri memakai produk daur ulang maka secara tidak langsung kita ikut mensosialisasikan gerakan penggunaan produk daur ulang. Unsur komunitas biasanya digunakan oleh kelompok masyarakat yang peduli akan lingkungan dan mereka yang memiliki cara pandang atau persepsi berbeda tentang produk daur ulang. Tidak sedikit orang yang merasa malu untuk menggunakan produk daur ulP;ang, mereka lebih memilih untuk menggunakan produk baru dengan brand ternama. Sedangkan pengguna dari unsur perusahaan atau badan usaha dapat menunjukkan bahwa perusahaan tersebut memiliki kepedulian terhadap lingkungan, bahkan dapat dijadikan sebagai salah satu upaya merealisasikan Program Corporate Social Responsibilities (CSR). Apalagi produk daur ulang tersebut berasal dari kemasan plastik yang diproduksi oleh perusahaan tersebut, berarti perusahaan secara langsung bertanggung jawab atas penggunaan sampah plastik yang dihasilkan oleh hasil produksinya. Peran konsumen / pengguna merupakan faktor penting dalam keberlangsungan usaha daur ulang, sehingga hubungan antara konsumen dan pengolah sampah adalah sebagai demand. Gambar. 5 menunjukkan alur produk daur ulang sampah plastik sampai ke konsumen/pengguna.

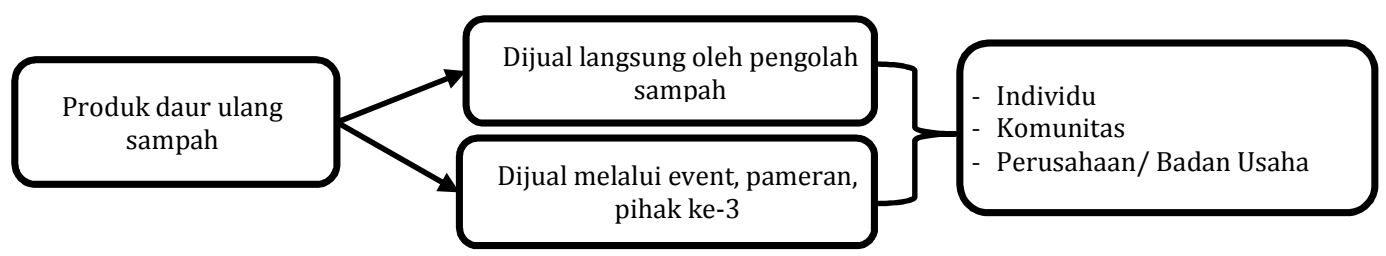

Gambar. 5 Alur produk daur ulang sampah ke konsumen / pengguna.

Tabel. 2 Identifikasi Faktor - faktor internal dan eksternal SWOT

FAKTOR INTERNAL DAN EKSTERNAL

S1 merupakan aktifitas yang memiliki dampak positif untuk mengurangi jumlah sampah plastik bahkan hingga 100\%

S2 merupakan aktifitas yang dapat menghasilkan uang

S3 merupakan aktifitas yang dapat mendukung keberlangsungan kelompok masyarakat pengolah sampah plastik

S4 merupakan aktifitas yang dapat membuka peluang lapangan pekerjaan

W1 pada saat ini masih merupakan aktifitas sambilan/bukan aktifitas utama sehingga belum bisa fokus $100 \%$ dalam mengelola sampah plastik

W2 tingkat kreatifitas dalam mencari ide desain yang naik turun sehingga terkadang mempengaruhi lamanya proses produksi

W3 alat yang digunakan untuk mengolah sampah plastik masih sederhana

W4 skala produksi masih kecil belum menghasilkan dapat memproduksi dalam jumlah massal

01 peluang bekerja sama dengan pemilik usaha yang menghasilkan sampah plastik/kemasan yang memiliki jenis yang sama dan jumlah yang banyak

02 mulai banyak stakeholder yang peduli terhadap masalah pengurangan sampah plastik (baik pemerintah, swasta, perusahaan, masyarakat)

03 peluang bekerja sama dengan kelompok masyarakat yang memiliki kegiatan bank sampah sebagai aktor pemasok bahan baku

04 peluang untuk mendorong pengembangan sistem informasi / aplikasi pengelolaan sampah

T1 masih kurangnya pemasok bahan baku yang sejenis untuk menghasilkan produk daur ulang

T2 harga komponen pelengkap yang relatif mahal sehingga mempengaruhi harga jual

T3 pola pikir masyarakat yang masih rendah minatnya dalam memakai barang / produk daur ulang

T4 minimnya informasi atau kegiatan yang mendukung dalam upaya pengelolaan sampah non organik terutama sampah plastik

Faktor internal dan faktor eksternal yang didapatkan dari responden untuk menentukan kekuatan (strengths - S), kelemahan (weaknesses - W), peluang (opportunities - 0), dan ancaman (threats - T). 
Tabel 2 merupakan daftar identifikasi faktor-faktor SWOT dalan pengolahan sampah plastik.

Dari Hasil Evaluasi Internal faktor dan Eksternal faktor maka didapatkan hasil alternatif strategi terbaik berada pada Kuadran I yaitu dengan menciptakan strategi yang menggunakan kekuatan untuk memanfaatkan peluang sebesar-besarnya. Alternatif tersebut adalah dengan bekerjasama dengan pemilik usaha yang menghasilkan sampah plastik/kemasan yang memiliki jenis yang sama dan jumlah yang banyak sebagai usaha untuk mengurangi jumlah sampah plastik untuk diolah menjadi barang yang memiliki nilai manfaat dan nilai ekonomis dan membuka peluang lapangan pekerjaan serta untuk mendorong pengembangan sistem informasi / aplikasi pengelolaan sampah (01,S1,S2,S4,04). Tujuan bekerjasama dengan pemilik usaha yang menghasilkan sampah plastik/kemasan yang memiliki jenis yang sama dan jumlah yang banyak dalah untuk memenuhi kebutuhan bahan baku dalam waktu yang lebih singkat. Sehingga proses pembuatan produk daur ulang tidak perlu memakan waktu yang lama untuk mendapatkan bahan baku, serta mendukung peningkatan jumlah produksi produk daur ulang yang dihasilkan. Semakin besar jumlah sampah plastik yang dapat dijadikan sebagai bahan baku produk daur ulang, maka semakin sedikit sampah plastik yang dibawa ke TPA. Suatu sistem penyediaan bahan baku, proses produksi hingga proses pemasaran sampai ke tangan konsumen, dibutuhkan dukungan teknologi baik berupa aplikasi sederhana yang memberikan informasi tentang ketersediaan jenis dan jumlah bahan baku yang terupdate, sehingga dapat mempersingkat waktu produksi. Selain itu juga perlu dukungan sistem informasi untuk membantu pemasaran produk daur ulang, sehingga jangkauan pengguna / konsumen akan lebih banyak dan lebih luas. Keberadaan teknologi informasi memegang peranan penting sebagai media untuk mempercepat terpenuhinya supply dan demand serta menjamin keberlanjutan usaha.

Kegiatan produksi daur ulang sampah tidak menghasilkan sampah baru, karena sisa - sisa bahan baku produksi dimanfaatkan kembali menjadi barang yang memiliki nilai manfaat yaitu untu membuat ecobrick. Ecobrick adalah bata ramah lingkungan, yang cara pembuatannya sederhana dengan memasukkan sampah plastik hasil dari proses produksi daur ulang ke dalam botol plastik, kemudian dimampatkan dengan menggunakan alat bantu kayu atau sumpit sampai botol penuh terisi dengan plastik, dan kondisinya keras apabila ditekan tidak berubah bentuk.

\section{Kesimpulan}

Pengelolaan sampah plastik merupakan kegiatan yang dilakukan untuk mengurangi volume sampah plastik yang jumlahnya cukup besar, yaitu sekitar $13,5 \%$ dari total seluruh sampah yang dihasilkan.
Salah satu upaya untuk mengurangi jumlah sampah plastik yang berkelanjutan dan berwawasan lingkungan adalah dengan kegiatan daur ulang sampah. Kegiatan daur ulang sampah merupakan suatu rangkaian kegiatan yang dimulai dari mengolah sampah plastik yang semula dianggap tidak memiliki nilai manfaat, menjadi produk daur ulang yang memiliki nilai manfaat, nilai estetis dan nilai ekonomis. Keberhasilan upaya tersebut tidak lepas dari rantai pasok yang merupakan rangkaian kegiatan yang diperlukan untuk merencanakan, mengendalikan, dan menjalankan arus produk. Kegiatan ini meliputi proses perolehan bahan baku, proses produksi, hingga distribusi produk ke konsumen akhir, dengan cara yang paling efisien dan hemat biaya.

Tingkat keberhasilan dan keberlanjutan dalam mengurangi sampah plastik dipengaruhi oleh peran dari masing-masing pelaku rantai pasok, mulai dari sumber penghasil dengan melakukan pemilahan sampah sesuai jenisnya kemudian sampah tersebut ditransfer ke bank sampah atau langsung ke pengolah sampah plastik, peran bank sampah yang dapat menjadi perantara antara sumber penghasil sampah dengan pengolah sampah plastik. Semakin banyak jumlah sumber penghasil sampah dan bank sampah yang bekerjasama dengan pengolah sampah plastik, akan menjamin terpenuhinya bahan baku produk daur ulang dengan cepat dan mudah. Nilai ekonomis keuntungan yang dihasilnya juga cukup baik antara 25-32\% dari biaya produksi yang diperlukan. s

Suatu sistem penyediaan bahan baku, proses produksi hingga proses pemasaran sampai ke tangan konsumen, dibutuhkan dukungan teknologi baik berupa aplikasi sederhana yang memberikan informasi tentang ketersediaan jenis dan jumlah bahan baku yang terupdate, sehingga dapat mempersingkat waktu produksi. Selain itu juga perlu dukungan sistem informasi untuk membantu pemasaran produk daur ulang, sehingga jangkauan pengguna / konsumen akan lebih banyak dan lebih luas. Keberadaan teknologi informasi memegang peranan penting sebagai media untuk mempercepat terpenuhinya supply dan demand serta menjamin keberlangsungan dan keberlanjutan usaha. Sampah yang dihasilkan dari proses produksi dimanfaatkan lagi menjadi barang yang memiliki nilai manfaat yaitu untuk membuat eco brick. Dengan demikian apabila rantai pasok ini berjalan sebagaimana mestinya, maka jumlah sampah plastik yang dibawa menuju ke TPA dapat berkurang menjadi $0 \%$.

\section{DAFTAR PUSTAKA}

Anwar, Sariyun Naja, 2011, "Manajemen Rantai Pasokan (Supply Chain Management): Konsep dan Hakikat", Jurnal Dinamika Informatika 3, No. 2

Badan Pusat Statistik Kota Semarang.2018. Kecamatan Semarang Tengah Dalam Angka 2018. CV. Citra Yuda, Semarang.

Badan Pusat Statistik Indonesia, 2017. Statistik Lingkungan Hidup Indonesia 2017. https://bps.go.id. 
Badan Standarisasi Nasional, SNI 19.3964.1994 tentang Metode Pengambilan dan Pengukuran Contoh Timbulan Sampah Perkotaan

Badan Standarisasi Nasional, SNI 19.3983.1995 tentang Spesifikasi Timbulan Sampah untuk Kota Kecil dan Kota Sedang di Indonesia

Badan Standarisasi Nasional, SNI 19.2454.2002 tentang Tata Cara Teknik Operasional Pengelolaan Sampah Perkotaan.

Badan Standarisasi Nasional, SNI 3234.2008 tentang Pengelolaan Sampah Permukiman

Direktorat Jenderal Cipta Karya Kementerian PUPR. DasarDasar Sistem Pengelolaan Sampah.

Ethariesta. 2015. Pengolahan sampah di Jerman. https://ethariesta.wordpress.com/tag/pengolahansampah-di-jerman/

Herdiawan,Junanto.2013. Rahasia sukses pengolahan sampah di Jepang. http://olahsampah.com/index.php/manajemensampah/39-rahasia-sukses-pengolahan-sampah-dijepang.

Ismiyati. 2011. Statistik dan Probabilitas untuk Teknik Bagi Peneliti Pemula, Magister Teknik Sipil Program Pascasarjana UNDIP, Semarang.

Peraturan Daerah Kota Semarang Nomor 2 Tahun 2012 tentang Retribusi Jasa Umum di Kota Semarang.

Peraturan Daerah Kota Semarang Nomor 6 Tahun 2012 tentang Pengelolaan Sampah.

Peraturan Daerah Provinsi Jawa Tengah Nomor 3 Tahun 2014 tentang Pengelolaan Sampah di Jawa Tengah.

Peraturan Pemerintah Nomor 81 Tahun 2012 tentang Pengelolaan Sampah Rumah Tangga dan Sampah Sejenis Sampah Rumah Tangga.

Peraturan Menteri Dalam Negeri Nomor. 33 Tahun 2010 tentang Pedoman Pengelolaan Sampah.

Peraturan Menteri Pekerjaan Umum Republik Indonesia Nomor 03/PRT/M/2013 tentang Penyelenggaraan Prasarana Dan Sarana Persampahan Dalam
Penanganan Sampah Rumah Tangga Dan Sampah Sejenis Sampah Rumah Tangga.

Peraturan Menteri Pekerjaan Umum Republik Indonesia Nomor : 01/PRT/M/2014 tentang Standar Pelayanan Minimal Bidang Pekerjaan Umum dan Penataan Ruang.

Purristiyana. 2011. Strategi Peningkatan Pelayanan Dinas Kebersihan Dan Pertamanan Dalam Pengelolaan Sampah Perumahan (Kajian Di Kabupaten Bogor), IPB, Bogor.

Rangkuti, F. (2013a). Analisis SWOT. Jakarta: PT Gramedia Pustaka Utama.

Rangkuti, F. (2013b). SWOT Balanced Scorecard (Ke-5th ed.). Jakarta: PT. Gramedia Pustaka Utama.

Setiawan A., Marimin, Arkeman Y., Udin F., 2011, Studi Peningkatan Kinerja Manajemen Rantai Pasok Sayuran Dataran Tinggi di Jawa Barat, Jurnal Aritech, Vol 31, No. 1, 60-70.

Setiawan S. A., 2011, Studi Peningkatan Kinerja Manajemen rantai pasok sayuran dataran tinggi terpilih di Jawa Barat, Disertasi, Doktoral, Teknologi Industri Pertanian, Institut Pertanian Bogor.

Seo, Yoonjung. 2013. Current Municipal Solid Waste Management and Waste to Energy Status in Republic of Korea, Columbia University, New York.

Sudokwon Landfill Site Management Corporation (SLC). 2010. Technology of Combustible Waste Sorting and RDF Manufacturing Facilities in Sudokwon Landfill, South Korea.

Tchobanoglous G, 1993. Integrated Solid Waste Management, Mc Graw-Hill International, New York.

Titisarinurul. 2016. Sistem Pengelolaan Sampah di Swedia. https://titisari04.wordpress.com/2016/11/15/siste m-pengolahan-sampah-di-swedia.

Undang-Undang Republik Indonesia Nomor 18 Tahun 2008 tentang Pengelolaan Sampah.

Universitas Diponegoro, Program Pasca Sarjana. 2017. Buku Panduan Tesis Magister Teknik Sipil, UNDIP, Semarang. 